This item was submitted to Loughborough's Research Repository by the author.

Items in Figshare are protected by copyright, with all rights reserved, unless otherwise indicated.

\title{
Expatriate cultural identity negotiation strategies: A dynamic framework
}

\section{PLEASE CITE THE PUBLISHED VERSION}

https://books.emeraldinsight.com/page/detail/Intercultural-Management-in-Practice/?K=9781839828270

\section{PUBLISHER}

Emerald

\section{VERSION}

AM (Accepted Manuscript)

\section{PUBLISHER STATEMENT}

This book chapter was published in the book Intercultural Management in Practice [@ Emerald]. The publisher's website is at: https://books.emeraldinsight.com/page/detail//ntercultural-Management-in-Practice/? $\mathrm{K}=9781839828270$

\section{LICENCE}

CC BY-NC-ND 4.0

\section{REPOSITORY RECORD}

Li, Chenchen, Ling Eleanor Zhang, and Anne-Wil Harzing. 2021. "Expatriate Cultural Identity Negotiation Strategies: A Dynamic Framework”. Loughborough University. https://hdl.handle.net/2134/15132231.v1. 


\section{Expatriate Cultural Identity Negotiation Strategies: A Dynamic Framework}

Chenchen Li, Southwestern University of Finance and Economics, China Ling Eleanor Zhang, Loughborough University London, United Kingdom Anne-Wil Harzing, Middlesex University London, United Kingdom

Version August 2021

Published as: Li, C, Zhang, LE, \& Harzing, AW (2021). Expatriate Cultural Identity Negotiation Strategies: A Dynamic Framework. Intercultural Management in Practice, in: Chavan, M. and Taksa, L. (eds). Intercultural Management in Practice, Bingley: Emerald, pp. 131-140.

Copyright $@ 2019-2021$ by the authors. All rights reserved.

Prof. Anne-Wil Harzing

Middlesex University The Burroughs, Hendon London NW4 4BT

Email: anne@harzing.com

Web: www.harzing.com 


\section{Expatriate Cultural Identity Negotiation Strategies: A Dynamic Framework ${ }^{i}$}

In an era characterized by global mobility, there is a resurgence of nationalism and increasingly unsettled international relations between the world's major political and economic powers. Identifying culturally competent employees for international assignments and tailoring supportive practices for their expatriation has thus become more challenging than ever before (Horak, Farndale, Brannen, \& Collings, 2019). In the current expatriation literature, there is a strong but unfounded assumption that expatriates are predominantly monocultural (Mao and Shen, 2015). However, one's cultural identity can change as a result of prolonged exposure to more than one culture (Berry \& Annis, 1974; Hong, Morris, Chiu, \& Benet-Martinez, 2000). Expatriates are powerful minority groups with access to unique resources and have considerable freedom to negotiate their cultural identities (Adams \& van de Vijver, 2015).

In this book chapter, we highlight expatriates' choice in conceptualizing cultural identity negotiation strategies and explore how organizations can better understand and manage expatriates from a dynamic cultural identity perspective. We propose a framework of how expatriates can develop different types of cultural identity negotiation strategies such as monocultural, multicultural, global, and cosmopolitan identity negotiation strategy (Levy, Schon, Taylor, \& Boyacigiller, 2007; Sussman, 2002).

We further draw upon research on globalization in psychology to explicate how expatriates develop exclusionary versus integrative responses towards host cultures. The perspective of exclusionary versus integrative reactions unpacks the psychological mechanisms linking expatriates' adoption of different cultural identity negotiation strategies with their responses towards the host culture. Exclusionary responses among expatriates are characterized by feelings of stress and anxiety associated with working in the host culture. Exclusionary emotions may further externalize as rejection of host culture employees and knowledge. In contrast, an integrative response leads expatriates to leverage components in the host culture for a fruitful expatriation experience and future career success. An understanding and appreciation of cultural differences helps expatriates to adjust to and perform well in the host culture (Chen \& Starosta, 2000; Fitzsimmons, 2013; Mol, Born, Willemsen, \& Molen, 2005), while psychological discomfort in the host culture is usually associated with poor mental health, low job performance and withdrawal (Hechanova, Beehr, \& Christiansen, 2003).

\section{Cultural identity, multicultural employees and expatriation success}

Cultural identity, the perception of belongingness to a cultural group (Hogg \& Terry, 2000), is a critical predictor of individual behaviors in intercultural settings. How individuals self-define themselves plays an important role in regulating motivation and affects, and in other intrapersonal and interpersonal processes (Markus \& Wurf, 1987). Research has shown that cultural identity facilitates the processing of certain types of information so that specific cultural knowledge may be cognitively accessible only for those who identify with the 
culture (Hong, et al., 2000). People who identify with one particular culture typically internalize its values, follow its norms and engage in cognitive processes that are consistent with the culture (Markus \& Kitayama, 1991).

Prior literature has investigated the role of different cultural identities in successful expatriation, including adjustment, performance, and expatriate turnover (Harrison \& Shaffer, 2005; Hom \& Griffeth, 1991). Identification with the host culture facilitates intercultural adjustment and performance because of access to knowledge and skills from multiple cultures (Gillespie, McBride \& Riddle, 2010). Global and cosmopolitan expatriates, who are culturally independent of the home culture and the host culture, also enjoy performance benefits resulting from their openness to multiple cultures and integration across cultures (Levy, et al., 2007; Maddux \& Galinsky, 2009). A recent empirical study found that employees with multiple cultural identities display higher levels of intercultural communication skills (Fitzsimmons, Liao, \& Thomas, 2017).

Moreover, the cultural learning associated with cultural identification plays an important role in expatriate adjustment and performance (Hechanova, et al., 2003). Individual characteristics that promote the understanding and embracing of cultural differences between the home and host cultures also contribute to successful expatriation. For example, being culturally sensitive helps expatriates adjust to the new cultural environment and perform better overseas (Bhatti, Battour, \& Ismail, 2013). Individuals who are motivated to appreciate cultural differences are likely to become effective intercultural communicators (Chen \& Starosta, 2000).

\section{Expatriate cultural identity negotiation strategies}

Identity negotiation strategies are jointly shaped by personal choice and environmental forces (Berry, 1997). Expatriates may adopt a monocultural strategy to maintain their home-culture identity in the host country. Monocultural expatriates connect their self-identities to their home culture and do not identify with the host culture (Shaffer, Harrison, Gregersen, Black, \& Ferzandi, 2006). Expatriates may also temporarily ascribe to new cultural identities through their experience with multiple cultures. Some may employ a multicultural strategy, identifying with their home culture as well as the host culture. As Berry (1997) proposed, maintaining the home cultural identity while being receptive to the host culture is a common acculturation strategy when adapting to a new cultural environment. For instance, some American expatriates begin to feel "more" Japanese some time into their assignment in Japan (Sussman, 2002).

In their negotiation of cultural identities, expatriates are not restricted to a choice between their home culture and the host culture. Globalization has witnessed the birth of global citizens who accept global interdependence and hence develop a strong sense of belongingness to a global community that transcends national boundaries (Arnett, 2002). A global identity negotiation strategy refers to expatriates employing neither the home culture nor the host culture to define self. Expatriates following a global identity negotiation strategy endorse a universal set of values, for example, mutual respect and protection of human rights (Appiah, 2006), and/or environmental responsibility and ethical behaviors (Shokef \& Erez, 2006). These universal values then guide expatriates during overseas assignments and 
allow them to maintain a global lifestyle anywhere in the world. MNCs with operations that span the world are usually keen to employ expatriates with a global mindset, especially for strategic business functions (Hong \& Doz, 2013).

Expatriates who employ a cosmopolitan strategy are culturally independent from the home and host culture yet are willing to engage with the host culture. Similar to global expatriates, cosmopolitans detach themselves from both their home culture and the host culture. Yet they perceive themselves as consumers of cultures and value their engagement with the host culture (Adams \& van de Vijver, 2015; Holt, 1997). As such, cosmopolitans are always ready to participate as members in a given culture (Adler, 1977). Different from their counterparts who employ a global identity, cosmopolitan expatriates do not subscribe to universal values. Cosmopolitan expatriates are usually good at learning new languages and fitting into a variety of different cultures (Brimm, 2010).

\section{Exclusionary versus integrative reactions}

\section{Expatriate responses towards the host culture}

Working in the host culture constantly presents expatriates with the cultural mixing of their own home culture and the host culture. The host cultural components are embedded in their working and living environment during their overseas assignments. Meanwhile, expatriates experience the home culture through their contact with families, friends, and colleagues in the home culture. Expatriates themselves may also serve as carriers of the home culture. Exposure to the cultural mixing of home culture and host culture may activate exclusionary and integrative reactions towards the host culture. Table 1 summarizes the major differences between these two types of responses.

Exclusionary reactions towards the host culture arise from the stress and anxiety associated with living and working in a new culture. Difficulties in understanding and controlling others' behaviors may cause expatriates to perceive the overseas assignment as disruptive. Expectations in terms of working styles and interpersonal norms might diverge or even be in opposition between their home culture and the host culture; expatriates are thus likely to experience uncertainty and conflict. Empirical research supports the view that role ambiguity and role conflict are primary sources of mal-adjustment and performance deficits during expatriation (Bhaskarshrinivas, Harrison, Shaffer, \& Luk, 2005; Kawai \& Mohr, 2015). To manage the uncertainty rooted in the host culture, expatriates might minimize interacting with host culture employees and other carriers of the host culture. Rejection of the host culture further induces frustration and stress as expatriates are still expected to conduct business in locally accepted ways. These exclusionary reactions are likely to result in mal-adjustment and a premature return from their assignment (Aycan, 1997; Shaffer, Harrison, \& Gilley, 1999). Therefore, expatriates' exclusionary responses towards the host culture have negative implications for expatriate adjustment and performance. 
Table 1. Expatriates' exclusionary and integrative responses towards the host culture

\begin{tabular}{|c|c|}
\hline Exclusionary responses & Integrative responses \\
\hline $\begin{array}{l}\text { Emotional responses to uncertainty } \\
\text { associated with the host culture }\end{array}$ & $\begin{array}{l}\text { Goal-oriented reactions to solve problems } \\
\text { with new knowledge in the host culture }\end{array}$ \\
\hline $\begin{array}{l}\text { Perception of working in the host culture: } \\
\text { disruptive conflicts }\end{array}$ & $\begin{array}{l}\text { Perception of working in the host culture: } \\
\text { growth opportunities }\end{array}$ \\
\hline Negative intercultural affects: stress, anxiety & Positive intercultural affects: admiration \\
\hline $\begin{array}{l}\text { Exclusionary behavioral reactions: } \\
\text { - social isolation from local employees; } \\
\text { - avoidance of local culture; } \\
\text { - cultural rejection }\end{array}$ & $\begin{array}{l}\text { Integrative behavioral reactions: } \\
\text { - active interactions with local } \\
\text { employees; } \\
\text { - learning about local language and } \\
\text { culture; } \\
\text { - creative integration }\end{array}$ \\
\hline High salience of home culture identity & A cultural learning mindset \\
\hline
\end{tabular}

Integrative reactions towards the host culture are goal-oriented actions that aim to solve problems by integrating cognitive resources from the host culture. Expatriates displaying integrative reactions perceive working in the host country as an opportunity for personal growth and career advancement. They show admiration and appreciation towards the host culture, thus further engaging with host culture employees and learning about the host culture. Interaction with host culture members is an effective way to acquire knowledge about culturally appropriate behaviors (Caligiuri, 2000). In addition, expatriates' integrative reactions help them to enhance learning during their expatriation as a result of new job roles, new performance standards and expectations from the host subsidiaries, all of which are critical to expatriate adjustment and performance (Gong \& Fan, 2006; Kramer, Wayne, \& Jaworski, 2001). Integrative responses also facilitate the development of global leadership skills, as best practices from various host cultures can be synthesized. In sum, integrative reactions towards the host culture have positive implications for expatriates' performance, subjective well-being, as well as the subsidiary performance as a whole.

\section{Psychological mechanisms underlying expatriates' responses}

The salience of home cultural identity and a cultural learning mindset serve as the main activators of expatriates' exclusionary and integrative responses towards the host culture (Chiu, Gries, Torelli, \& Cheng, 2011). A salient home cultural identity guides information categorization and processing through the lens of the home culture (Chiu, et al., 2011). Simultaneous exposure to two different cultures elevates perceived cultural incompatibility and highlights the different characteristics of these two cultures (Torrelli, Chiu, Tam, Au, \& Keh, 2011); this is likely to cause a sense of uncertainty among expatriates. The salience of home cultural identity further guides expatriates' attribution of perceived stress and anxiety to the host culture. For instance, expatriates may make unfavorable comparisons between the host culture and their home culture (Stahl \& Caligiuri, 2005). A salient home cultural identity is therefore likely to activate expatriates' exclusionary reactions towards the host culture. 
Expatriates with a cultural learning mindset are keen to acquire cultural knowledge. Appreciation and an understanding of cultural differences between the home and host culture promote appropriate intercultural communication (Chen \& Starosta, 2000) and expatriate job performance (Mol, et al., 2005). In addition, living and working in the host culture presents alien experiences in numerous domains. A cultural learning mindset encourages expatriates to expose themselves to distinctive or even opposing opinions and experiences rooted in the host culture. Attempts at the integration of novel components from foreign cultures nurtures cognitive complexity - a cognitive ability that helps people to capitalize on the creativity benefits embedded in multicultural experiences (Tadmor, Galinsky, \& Maddux, 2012). Therefore, expatriates with a cultural learning mindset are more likely to engage in integrative reactions towards the host culture.

\section{Identity negotiation strategies and expatriates' responses}

The salience of home cultural identity and a cultural learning mindset differentiate monocultural, multicultural, global, and cosmopolitan strategies among expatriates, thus serving as the inter-mediatory mechanism linking cultural identity negotiation strategies and expatriates' responses. The associations between expatriates' identity negotiation strategies and their exclusionary and integrative reactions are summarized in Figure 1. An animal analogy (Harzing, 2001) is included for each cultural identity negotiation strategy to illustrate and clarify the differences between the four strategies.

Figure 1. The associations between cultural identity negotiation strategies and expatriate responses

High salience of home culture identity

\begin{tabular}{|c|c|c|}
\hline $\begin{array}{l}\text { Absence } \\
\text { Cultural } \\
\text { Learning } \\
\text { Mindset }\end{array}$ & $\begin{array}{l}\text { Monocultural strategy } \\
\text { Mainly exclusionary } \\
\text { reactions }\end{array}$ & $\begin{array}{l}\text { Multicultural strategy } \\
\text { Both exclusionary and } \\
\text { integrative reactions }\end{array}$ \\
\hline & $\begin{array}{l}\text { Global strategy } \\
\text { Neither exclusionary nor } \\
\text { integrative reactions }\end{array}$ & Mainly integrative reactions \\
\hline
\end{tabular}


Monocultural expatriates rely on the values and behavioral norms rooted in their home cultures to guide them when working in the host country. This is labelled as the "ostrich" strategy. The ostrich is chosen as an analogy, because it symbolizes the image of an individual burying their head in the sand and ignoring the host culture. The cognitive closed-mindedness associated with a monocultural strategy inhibits expatriates from engaging in integrative reactions towards the host culture, thus preventing expatriates from leveraging knowledge and practices in the host culture for creative benefits and the development of global leadership skills. Expatriates employing a monocultural strategy tend to have a salient home cultural identity and lack a cultural learning mindset towards the host culture. Therefore, expatriates employing a monocultural identity negotiation strategy are more likely to develop exclusionary responses and are less likely to engage in integrative responses towards the host culture.

A multicultural identity negotiation strategy refers to expatriates choosing to identify with the host culture while maintaining their home cultural identity. This is labelled as the "frog" strategy, because frogs can live both in the water and on the land. Expatriates following a multicultural strategy are receptive to internalizing the host culture, while maintaining their home culture as an important part of their self-identity. The cultural mixing of the home culture with the host culture during expatriation therefore activates exclusionary responses towards the host culture. Yet, expatriates employing a multicultural strategy are also willing to acquire and internalize values and knowledge of the host culture; the cultural learning mindset among expatriates following a multicultural identity negotiation strategy activates expatriates' integrative reactions towards the host culture. Therefore, a multicultural identity negotiation strategy is associated with both exclusionary and integrative responses among expatriates in the host culture.

Whether exclusionary or integrative responses are activated among multicultural expatriates depends on the perceived compatibility between their home culture and the host culture (Benet-Martínez \& Haritatos, 2005). When expatriates perceive the host culture to be in conflict with their home culture, their multicultural strategy is dominated by a salient home culture identity, leading to exclusionary responses towards the host culture. On the contrary, perceived harmony between the home culture and the host culture elevates the role of cultural learning mindset in a multicultural strategy, thus activating integrative response.

A global identity negotiation strategy enables expatriates to work and socialize in the host culture through deploying universal work styles and communication patterns across cultures. This strategy is represented with the metaphor of a "bird" symbolizing the detachedness from the host and home culture (in the same way that birds do not live on the ground but fly in the sky). For expatriates employing a global identity negotiation strategy, moving into a new host culture highlights their sense of belongingness to a global community (Sussman, 2002) rather than activating the salience of their home cultural identity. Therefore, expatriates following a global cultural identity negotiation strategy are less likely to display exclusionary reactions towards the host culture. Although they are open to cultural diversity, they do not have a strong motivation to engage with the host culture (Hanek, Lee, \& Brannen, 2014); possibly because their belief in the transcendence of values beyond cultural boundaries results in the perception of the host culture as part of a large global village. Because these expatriates typically possess high levels of intercultural competence, inclusive 
of interpersonal sensitivity and open-mindedness (Dewaele \& Van Oudenhoven, 2009; Lyttle, Barker, \& Cornwell, 2011), they do not possess a strong motivation to learn about specific aspects of the host culture. The study therefore proposes that a global identity negotiation strategy does not activate either expatriates' exclusionary or integrative responses towards the host culture.

Expatriates employing a cosmopolitan identity negotiation strategy do not subscribe to the home culture in their self-definition but do engage with the host culture during their overseas assignments. This strategy is represented with the metaphor of "lizard" because the skin color of a lizard adapts to its surroundings. The cultural independence of these expatriates suppresses information processing through the lens of their home culture, thus preventing the activation of salient home cultural identity. Therefore, working in the host culture is less likely to evoke exclusionary reactions towards the host culture among these expatriates. Expatriates employing a cosmopolitan strategy are willing to learn about the host culture; they consume cultural products from many cultures and appreciate cultural novelty (Levy et al., 2007). As cultural connoisseurs, they are motivated to experience the host culture (e.g., Hannerz, 1990; Hannerz, 1996), and thus have more exposure to alien knowledge embedded in the host culture. Because these expatriates are able to detach themselves from both the home culture and the host culture, their "outsider" status allows them a peripheral position from which to absorb and integrate seemingly incompatible components from different sources for creativity and innovation (Van Kleef, Steinel, \& Homan, 2013). Meanwhile, these expatriates also wear the "insider" hat to actively interact with host culture employees and learn about the host culture. Therefore, a cosmopolitan identity negotiation strategy facilitates expatriates' engagement with integrative reactions towards the host culture.

\section{Managerial implications}

The proposed framework of expatriate identity negotiation strategies is applicable to a broader category of mobile workforces who are exposed to a multicultural working environment. Technological developments transform the ways that people experience foreign cultures. Foreign cultural elements are prevalent in the workplace and in the media. Scholars have further identified global domestic and global virtual team members as subgroups of global workers that are responsible for interaction with stakeholders from other cultures (e.g. Shaffer, et al., 2012). Employees experiencing exposure to foreign cultures in such a virtual way are also likely to employ one of the identity negotiation strategies discussed above in order to navigate a multicultural environment. For instance, a local employee located in a global virtual team may gradually develop a cosmopolitan identity negotiation strategy as a result of interactions with colleagues from other cultures. Therefore, the proposed framework of expatriates' cultural identity negotiation strategies also offers insights into managing non-expatriate employees in a multicultural workplace.

Expatriates may adopt different strategies when facing assignments in different host cultures. For example, an Asian American employee is likely to take advantage of his/her Asian ancestry and employ a multicultural strategy when assigned to work in an Asian subsidiary. (S)he may choose a different strategy such as a monocultural strategy, global strategy or cosmopolitan strategy during deployment to a South American office. When expatriates 
choose the same strategy consistently across different host cultures over a long period of time, they may internalize their choice as a stable cultural identity type and become a monocultural/multicultural/global/cosmopolitan individual. On the other hand, expatriates may even adopt different strategies in the same host culture. For example, the same Asian American expatriate may use a cosmopolitan strategy when addressing his/her local subordinates and a global strategy in a meeting with other expatriates from various countries.

\section{Conclusion}

Cultural identity has significant implications for expatriate adjustment and performance. Yet to date, the scholarly understanding of expatriates' identity negotiation strategies is limited to a small group of born multicultural employees. This chapter provides a dynamic framework explaining monocultural, multicultural, global and cosmopolitan identity negotiation strategies among the broader population of expatriates during overseas assignments, and elucidates the psychological mechanisms underlying the associations between these identity negotiation strategies and expatriates' responses towards the host culture. Contrary to the recent literature on multicultural employees that has downplayed the notion of choice, this chapter sees expatriates as active agents who can choose their cultural identity negotiation strategies based on their own preferences and environmental demands. It thus provides a solid conceptual ground for future empirical research on understanding the cultural identity of corporate expatriates from a dynamic perspective.

\section{References}

Adams, B. G. and van de Vijver, F. J. (2015), "The many faces of expatriate identity", International Journal of Intercultural Relations, Vol. 49, pp. 322-331.

Adler, P. (1977), "Beyond cultural identity: Reflections on multiculturalism", In: Brislin R. (Ed.) Cultural Learning: Concepts, Applications, and Research. Honolulu, HI: The University Press of Hawaii, pp. 24-41.

Appiah, K.A. (2006), Cosmopolitanism: Ethics in a World of Strangers. W.W. Norton and Company, New York and London.

Arnett, J. J. (2002), "The psychology of globalization", American Psychologist, Vol. 57 No. 10, pp. 774-783.

Aycan, Z. (1997), "Expatriate adjustment as a multifaceted phenomenon: individual and organizational level predictors", The International Journal of Human Resource Management, Vol. 8 No. 4, pp. 434-456.

Berry, J. W. (1997), "Immigration, acculturation, and adaptation", Applied Psychology: An International Review, Vol. 46 No. 1, pp. 5-34.

Berry, J. W. and Annis, R. C. (1974), "Acculturative stress: The role of ecology, culture and differentiation", Journal of cross-cultural psychology, Vol. 5 No. 4, pp. 382-406.

Benet-Martínez, V. and Haritatos, J. (2005), "Bicultural Identity Integration (BII): components and psychosocial antecedents", Journal of Personality, Vol. 73 No. 4, pp. 1015-1049.

Bhaskarshrinivas, P. Harrison, D. A. Shaffer, M. A. and Luk, D. M. (2005), "Input-based and time-based models of international adjustment", Academy of Management Journal, Vol. 48 No.2, pp. 257-281.

Bhatti, M. A., Battour, M. M., and Ismail, A. R. (2013), "Expatriates adjustment and job performance: An examination of individual and organizational factors", International Journal of Productivity and 
Performance Management, Vol. 62 No. 7, pp. 694-717.

Brimm, L. (2010), Global cosmopolitans: the creative edge of difference. Palgrave Macmillan.

Caligiuri, P. M. (2000), "Selecting expatriates for personality characteristics: A moderating effect of personality on the relationship between host national contact and cross-cultural adjustment", Management International Review, Vol. 40 No.1, pp. 61-80.

Chen, G. M. and Starosta, W. J. (2000), "The development and validation of the intercultural sensitivity scale", Human Communication, Vol. 3 No. 1, pp. 1-15.

Chiu, C. Y., Gries, P. Torelli, C. J. and Cheng, S. Y. Y. (2011), "Towards a social psychology of globalization", Journal of Social Issues, Vol. 67 No. 4, pp. 663-676.

Dewaele, J. and Van Oudenhoven, J. (2009), "The effect of multilingualism / multiculturalism on personality: No gain without pain for third culture kids? " International Journal of Multilingualism, Vol. 6 No. 4, pp. 443-459.

Fitzsimmons, S. (2013), "Multicultural employees: A framework for understanding how they contribute to organizations", Academy of Management Review, Vol. 38 No. 4, pp. 525-549.

Fitzsimmons, S., Liao, Y. and Thomas, D. C. (2017), "From crossing cultures to straddling them: An empirical examination of outcomes for multicultural employees", Journal of International Business Studies, Vol. 48 No. 1, pp. 63-89.

Gillespie, K., McBride, J. B. and Riddle, L. (2010), "Globalization, biculturalism and cosmopolitanism: The acculturation status of Mexicans in upper management", International Journal of Cross Cultural Management, Vol. 10 No. 1, pp. 37-53.

Gong, Y. and Fan, J. (2006), "Longitudinal examination of the role of goal orientation in cross-cultural adjustment", Journal of Applied Psychology, Vol. 91 No. 1, pp. 176-184.

Hanek, K. J., Lee, F. and Brannen, M. Y. (2014), "Individual differences among global/multicultural individuals: Cultural experiences, identity, and adaptation", International Studies of Management and Organization, Vol. 44 No. 2, pp. 75-89.

Hannerz, U. (1990), "Cosmopolitans and locals in world culture", Theory, Culture and Society, Vol. 7 No. 2, pp. 237-251.

Hannerz, U. (1996), Transnational Connections: Culture, People, Places. London and New York: Routledge.

Harrison, D. A. and Shaffer, M. A. (2005). "Mapping the criterion space for expatriate success: task-and relationship-based performance, effort and adaptation", The International Journal of Human Resource Management, 16(8), 1454-1474.

Harzing, A.W. (2001). "Of bears, bumble-bees, and spiders: the role of expatriates in controlling foreign subsidiaries", Journal of World Business, Vol. 36 No.4, pp. 366-379.

Hechanova, R., Beehr, T.A. and Christiansen, N.D. (2003), "Antecedents and consequences of employees' adjustment to overseas assignment: A meta-analytic review", Applied Psychology: An International Review, Vol. 52 No. 2, pp. 213-236.

Hogg, M. A. and Terry, D. I. (2000), "Social identity and self-categorization processes in organizational contexts", Academy of Management Review, Vol. 25 No. 1, pp. 121-140.

Holt, D. B. (1997), "Poststructuralist lifestyle analysis: Conceptualizing the social patterning of consumption in postmodernity", Journal of Consumer Research, Vol. 23 No. 4, pp. 326-350.

Hom, P.W. and Griffeth, R.W. (1991), "Structural equations modeling test of a turnover theory: Cross-sectional and longitudinal analyses", Journal of Applied Psychology, Vol. 6, pp. 350-366.

Hong, H.-J. and Doz, Y. (2013), "L’Oreal Masters Multiculturalism”, Harvard Business Review, Vol. 91 No. 6, pp. 114-118.

Hong, Y., Morris, M., Chiu, C. and Benet-Martinez, V. (2000), "Multicultural minds: A dynamic constructivist approach to culture and cognition", American Psychologist, Vol. 55 No. 7, pp. 709-720.

Horak, S., Farndale, E., Brannen, M. Y. and Collings, D. G. (2019), "International human resource management in an era of political nationalism", Thunderbird International Business Review, Vol. 61 
No. 3, pp. 471-480.

Kawai, N. and Mohr, A. T. (2015), "The contingent effects of role ambiguity and role novelty on expatriates' work-related outcomes", British Journal of Management, Vol. 26 No. 2, pp. 163-181.

Kramer, M., Wayne, S. and Jaworski, R. (2001), "Sources of support and expatriate performance: The mediating role of expatriate adjustment", Personnel Psychology, Vol. 54 No. 1, pp. 71-99.

Levy, O., Schon, B., Taylor, S. and Boyacigiller, N. A. (2007), "What we talk about when we talk about 'global mindset': Managerial cognition in multinational corporations", Journal of International Business Studies, Vol. 38 No. 2, pp. 231-258.

Lyttle, A., Barker, G. and Cornwell, T. (2011), "Adept through adaptation: Third culture individuals' interpersonal sensitivity", International Journal of Intercultural Relations, Vol. 35 No. 5, pp. 686-694.

Maddux, W. W. and Galinsky, A. D. (2009), "Cultural borders and mental barriers: the relationship between living abroad and creativity", Journal of Personality and Social Psychology, Vol. 96 No. 5, pp. 1047-1061.

Markus, H. R. and Kitayama, S. (1991), "Culture and the self: Implications for cognition, emotion and motivation", Psychology Review, Vol. 98 No. 2, pp. 224-253

Markus, H. R. and Wurf, E. (1987), "The dynamic self-concept: A social psychological perspective", Annual Review of Psychology, Vol. 38 No. 1, pp. 299-337.

Mao, J., \& Shen, Y. (2015). Cultural identity change in expatriates: A social network perspective. Human Relations, Vol. 68 No. 10, pp. 1533-1556.

Mol, S. T., Born, M. P., Willemsen, M. E. and Molen, H. T. V. D. (2005), "Predicting expatriate job performance for selection purposes: A quantitative review", Journal of Cross Cultural Psychology, Vol. 36 No. 5, pp. 590-620.

Shaffer, M. A., Harrison, D. A. and Gilley, K., M. (1999), "Dimensions, determinants, and differences in the expatriate adjustment process", Journal of International Business Studies, Vol. 30 No. 3, pp. 557-581.

Shaffer, M. A., Harrison, D. A., Gregersen, H. B., Black, J. S. and Ferzandi, L. A. (2006), "You can take it with you: Individual differences and expatriate effectiveness. Journal of Applied Psychology, Vol. 91 No. 1, pp. 109-125.

Shokef, E. and Erez, M. (2006), "Global work culture and global identity, as a platform for a shared understanding in multicultural teams", In Y.-R. Chen (Ed.), Research on Managing Groups and Teams, Volume 9, Emerald Group Publishing Limited, pp. 325-352.

Stahl, G. K. and Caligiuri, P. (2005), "The effectiveness of expatriate coping strategies: The moderating role of cultural distance, position level, and time on the international assignment", Journal of Applied Psychology, Vol. 90 No. 4, pp.603-615.

Sussman, N. M. (2002), "Testing the cultural identity model of the cultural transition cycle: Sojourners return home", International Journal of Intercultural Relations, Vol. 26 No.4, pp. 391-408.

Tadmor, C. T., Galinsky, A. D. and Maddux, W. W. (2012), "Getting the most out of living abroad: biculturalism and integrative complexity as key drivers of creative and professional success", Journal of Personality and Social Psychology, Vol. 103 No. 3, pp. 520-542.

Torrelli, C. J., Chiu, C.-y., Tam, K.-p., Au, A. K.-C. and Keh, H. T. (2011), "Exclusionary reactions to foreign culture: Effects of simultaneous exposure to culture in globalized space", Journal of Social Issues, Vol. 67 No.4, pp. 716-742.

Van Kleef, G. A., Steinel, W. and Homan, A.C. (2013), "On being peripheral and paying attention: Prototypicality and information processing in intergroup conflict", Journal of Applied Psychology, Vol. 98 No.1, pp. 63-79.

\footnotetext{
' This is a shortened version of: Li, C, Zhang, LE, Harzing, A-W (2019) Of Ostriches, Frogs, Birds and Lizards: A Dynamic Framework of Cultural Identity Negotiation Strategies in an Era of Global Mobility, Journal of Global Mobility, 7(3), 239-254.
} 